titles as "The Teaching of Elementary Mathematics" and "Secondary Education in Australia", which have done much to give direction and purpose to mathematical teaching in the State right up to the present time.

Carslaw's interests in mathematics were wide, as a list of his principal works shows : "An Introduction to the Theory of Fourier Series and Integrals and the Mathematical 'Theory of the Conduction of Heat", first published in 1906 and rewritten and published as two separate volumes in 1921 ; "Plane Trigonometry" (1909) ; "Elements of Non-Euclidean Plane Geometry and Trigonometry" (1916); and "Operational Methods in Applied Mathematics" (1948, with J. C. Jaeger). Each of these contains work which is Carslaw's own contribution to the subject. The earlier works were many times reprinted and were standard text-books for more than a quarter of a century. The "Fourier Series" and the "Conduction" were translated into Japanese, and the "Conduction" was reprinted and widely circulated in the United States during the Second World War.

From 1916 onwards he published from time to time articles in the Mathematical Gazette and elsewhere on "Progressive Income Tax", and was consulted by the Commonwealth Treasury on the formulæ to be adopted, the aim of the formulæ being to give a continuous increase of rate of tax over quite a long range of incomes; such formulæ were in use until quite recently.

After retiring from the chair of mathematics in Sydney in 1935, Carslaw spent all his time on his small orchard property at Burradoo, eighty miles from the University, and only rarely went to the city. But his interest in mathematics continued unabated, until within the past three years failing sight made it impossible for him to continue. After the War, while in his late seventies, he had several years of fruitful collaboration with one of his students of twenty years earlier, now Prof. J. C. Jaeger. The fruits of this collaboration were the revised third edition of the "Conduction", and the "Operational Methods" mentioned above.

In 1907 Carslaw married Ethel Maude, the daughter of Sir William Clark, but she died within the year. Thereafter, Carslaw took little part in the social life of the University of Sydney; but he contributed with his characteristic vigour and vivacity to all other phases of University activity. T. G. Room

\section{Sir Frederick McMaster}

Sir Frederick Duncan McMaster died at his home at Dalkeith Station, Cassilis, N.S.W., on November 28. He was one of Australia's best-known pastoralists and a prominent studmaster. One of his main interests was breeding merino sheep, and he gradually built up the world-famous Dalkeith Stud. Sheep from this stud won many prizes in competition, and at one time a ram from this stud held the world's record for the greatest price.

Sir Frederick was interested in and supported many plans for the improvement of Australia's pastoral industry. He was always anxious and willing to help the small man. On one occasion he presented the Government with five hundred merino rams valued at $£ 4,000$ for distribution to small-scale farmers who had been badly affected by the depression. He was also interested in beef-cattle breeding. His success was well recognized by many prizes at the Sydney Royal Show.
In 1929 the Prime Minister made an appeal for public support for research into Australian primary industries. Sir Frederick responded by the presentation of $£ 20,000$ for the erection of a laboratory for the investigation of animal health problems. This laboratory, known as the McMaster Animal Health Laboratory, was erected for the Commonwealth Council for Scientific and Industrial Research at the University of Sydney. A great deal of invaluable research has been done at this laboratory. When it became known to Sir Frederick in recent months that the McMaster Laboratory was in urgent need of additional space, he spontaneously instructed his solicitors to arrange for Commonwealth bonds to the value of $£ 52,800$ to be made available to the University of Sydney for the erection of a wing to the Laboratory.

Sir Frederick took a keen interest in research, particularly in agriculture. He was a member of the N.S.W. State Advisory Committee of the Commonwealth Scientific and Industrial Research Organization for many years. $\mathrm{He}_{e}$ provided facilities on his own properties for scientists to carry out field-work, and leased 2,000 acres of Hinchinbrook Estate to assist scientific research. He was a keen observer and co-operated with the Meteorological Office in obtaining and keeping complete meteorological records. He was a prominent member of the Royal Agricultural Society of New South Wales and also an honorary life member of the Royal Agricultural Society of England.

Sir Frederick was born in 1873 and was educated at the Sydney Grammar School. In 1934 he was created a knight bachelor in recognition of his great services. By his death, Australia has lost a great pastoralist, a keen supporter of scientific work, and a generous benefactor.

J. R. A. McMmLAN

\section{NEWS and VIEWS}

\section{Sunspots of the New Cycle}

The Astronomer Royal reports the appearance of two sunspots that are the first sizable spots of the new eleven-year cycle. Particulars of these are as follows :

$\begin{array}{cccc}\text { Date on sun's disk } & \text { Central meridian passage } & \text { Latitude } & \text { Area } \\ \text { (v.T.) } & & \\ \text { Jan. } 2-14 & \text { Jan. } 8 \cdot 1 & 20^{\circ} \mathrm{N} . & 400 \\ \text { Jan. } 7-19 & \text { Jan. } 13 \cdot 1 & 36^{\circ} \mathrm{N} \text {. } & 800\end{array}$

The areas were measured on January 9 , the previous days having been overcast. The unit of area is onemillionth of the sun's hemisphere. In addition to the above two spots, an earlier one (probably of comparable size) was observed at Edinburgh on December 30 during the overcast period at Herstmonceux. This spot group, in latitude $24^{\circ}$ south, must have developed suddenly between December 28 and 30 , and would have passed off the sun's disk on January 5.

The sunspot eycle, with its great peak of activity in 1947 , presumably ended just before the middle of 1954. There has been the characteristic overlap in latitude of the old-cycle spots petering out in equatorial regions and the increasing incidence of the small new-cycle spots in latitude $20^{\circ}-40^{\circ}$. Any remaining doubt concerming the epoch of minimum significant to $1954 \cdot 4$ is now removed by the appearance of these definite spot groups, indicating that the new eleven-year cycle has now definitely begun. 